Вишняков Л. Р. ${ }^{1}$, Красовський В. ПI. ${ }^{1}$, Кохана I. М. ${ }^{1}$, Чернявський I. ${ }^{2}{ }^{2}$, Коханий В. О. ${ }^{1}$, Яременко О. П. ${ }^{1}$, Красовсъка Н. О. ${ }^{1}$

${ }^{1}$ Інститут проблем матеріалознавства ім. І. М. Францевича НАН України. Україна, м. Київ

${ }^{2}$ Державне підприємство «АНТОНОВ». Україна, м. Київ

\title{
РОЗРОБКА В’ЯЗАНО-ПАЯНИХ СІТОК-БЛИСКАВКОВІДВОДІВ З БЕЗСВИНЦЕВИМ ПРИПОЕМ ДЛЯ ЗАХИСТУ ПОЛІМЕРНИХ КОМПОЗИТІВ ВІД ДІї ПРЯМОГО УДАРУ БЛИСКАВКИ
}

Розглянуто механізм дисипації енергї блискавки при прямому влученні у вуглещьпластикову конструкцію, що захищена сіткою-блискавковідводом. Запропонована геометрична модель струмовідводної структури в'язано-паяної сітки з електричними структурними ланцюгами, що визначають електропровідність сітчастого полотна, розроблена методика розрахунку питомого поверхневого електроопору. Розроблено методичний підхід для дослідження кутів змочування міді безсвинцевими припоями, вивчені їх питомі електричні опори. Як припій сітчастого блискавковідводу рекомендовано застосовувати безсвинцевий сплав типу SAC (Sn-3,8\%Ag-0,7\% Cu). [dx.doi.org/10.29010/081.5]

Ключові слова: блискавкозахист; вуглеиьпластик; сітчасте полотно; металевий дріт; зв'язуюче; дисипація енергії.

\section{Вступ}

В результаті аналізу технічної інформації про існуючі схеми захисту від прямих ударів блискавки авіаційної техніки і з урахуванням власного досвіду нами були визначені конструктивні особливості системи блискавкозахисту полімерних композитів (ПКМ) для літаків цивільної авіації.

Принцип блискавкозахисту вуглецьпластику заснований на зниженні поверхневого електроопору конструкції за рахунок наформовки на поверхню композиту металевих покриттів [1].
3 цією метою в ІПМ НАН України разом із ДП «Антонов» розроблені сітчасті блискавковідводи та організовано серійний випуск в'язано-паяних сітокблискавковідводів. Сітки виготовляються на трикотажному обладнанні з мідних мікродротів діаметром 0,08 мм та 0,12 мм, що покриті припоєм ПОС-61, i пропаюються в петельних вузлах тим же припоєм [2]. Ці сітки-блискавковідводи мають марки, відповідно, МЭУ-0,08 та МЭУ-0,12 і широко використовуються заводами авіаційної промисловості.

При всіх своїх позитивних характеристиках ці сітки-блискавковідводи мають суттєвий недолік -

(c) Вишняков Л. Р., Красовський В. П., Кохана I. М., Чернявський І. І., Коханий В. О., 
використання свинецьмісткого припою ПОС-61. Незважаючи на те,що сплави на основі свинцю мають високу рідкоплинність, корозійну стійкість і є високотехнологічними, на Свропейському ринку, починаючи з 2006 року,вони заборонені для використання в припоях. Це пов'язано з токсичністю свинцю і його негативним впливом на організм людини.

\section{Мета роботи}

Мета цього дослідження - вивчити механізм захисної дії сіток-блискавковідводів МЭУ-0,08 та МЭУ-0,12, а також виявити можливість заміни в сітках-блискавковідводах припою ПОС-61 на безсвинцевий припій за результатами розрахунків та стендових випробувань вражаючої дії імітованої блискавки на стандартну вуглецьпластикову панель.

\section{Результати досліджень}

Пропайка структурних елементів (чарунок) блискавкозахисних сіток значно знижує їх питомий поверхневий електроопір (табл. 1), особливо в повздовжньому напрямі. При враженні блискавкою процеси плавлення і випаровування легкоплавкого припою при нагріві сітчастого полотна призводять до зменшення величини тепловиділення, тим самим зменшуючи температуру нагріву ПКМ.

Дисипація теплової енергії блискавки сітками призводить також до релаксації механічних напружень, які зазвичай виникають у вуглецьпластику при його нагріві та призводять до деструкції зв'язуючого, інтенсивного газовиділення i, як результат, до розшарування і руйнування вуглецьпластика.

Процес плавлення припою в пропаяних нерухомих з'єднаннях петель сприяє плавному ослабленню механічного зв’язку між сусідніми петлями. Збільшена при цьому рухомість петель, що розташовані на поверхні панелі, підсилює ефект релаксації механічних напружень та сприяє зменшенню пошкодження панелей.

Панелі для розрядних випробувань виготовлялися на ДП «Антонов» методом вакуумного автоклавного формування. Випробування панелей дією струмів імітованої блискавки проводили на сертифікованому стенді в НДПКІ «Молнія», м. Харків. Захисні властивості сітки-блискавковідводуМЭУ0,12 (табл. 2) демонструють результати стендових випробувань вуглецьпластикових панелей нормованими імпульсами струмів блискавки за умови зони 1А [3]. Результати випробувань,що приведені в таблиці 2 (панель №1), відображають захисну дію сітки-блискавковідводу МЭУ 0,12, що здатна відводити по поверхні вуглецьпластика практично всю енергію блискавки, і відповідають умовам авіаційних правил АП-25 [3].

Слід зазначити, що вуглецьпластик, захищений сіткою МЭУ 0,12, який має більшу питому електропровідність (порівняно із захищеним сіткою МЭУ $0,08)$ доцільно розташовувати в найбільш відповідальних місцях літака, наприклад, для захисту від дії блискавки паливних баків, в яких присутні авіаційне паливо і його пари.

Таблиця 1

\section{Властивості блискавкозахисних мідних сіток трикотажної структури}

\begin{tabular}{|c|c|c|c|c|c|c|c|c|}
\hline \multirow[b]{2}{*}{ 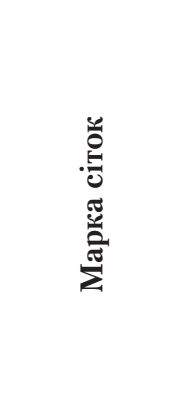 } & \multicolumn{3}{|c|}{ Структура сіток } & \multicolumn{2}{|c|}{$\begin{array}{c}\text { Технологічні } \\
\text { властивості сіток }\end{array}$} & \multicolumn{3}{|c|}{$\begin{array}{c}\text { Питомий поверхневий } \\
\text { електричний опір сіток, мОм }\end{array}$} \\
\hline & 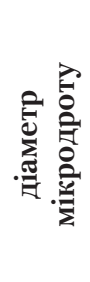 & 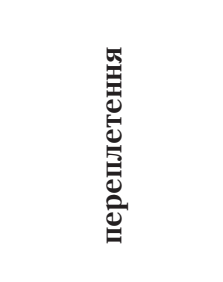 & 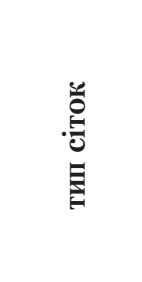 & 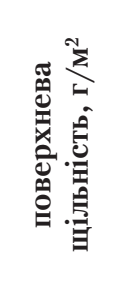 & 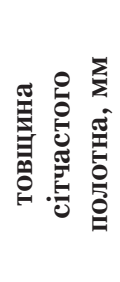 & 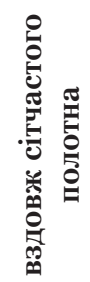 & 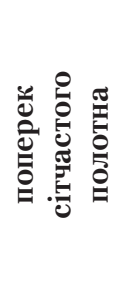 & 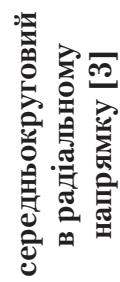 \\
\hline МЭУ-0,08 & 0,08 & «ластик 1+1» & $\begin{array}{l}\text { в'язано- } \\
\text { паяна }\end{array}$ & $105_{-5}^{+20}$ & 0,15 & 4,42 & 4,86 & 4,72 \\
\hline МЭУ-0,12 & 0,12 & «ластик 1+1» & $\begin{array}{l}\text { в'язано- } \\
\text { паяна }\end{array}$ & $155_{-5}^{+20}$ & 0,23 & 3,25 & 3,55 & 3,36 \\
\hline СВМ-БП & 0,1 & «ластик 1+1» & $\begin{array}{l}\text { в'язано- } \\
\text { паяна }\end{array}$ & $135 \pm 5$ & 0,18 & 3,32 & 3,74 & 3,42 \\
\hline
\end{tabular}




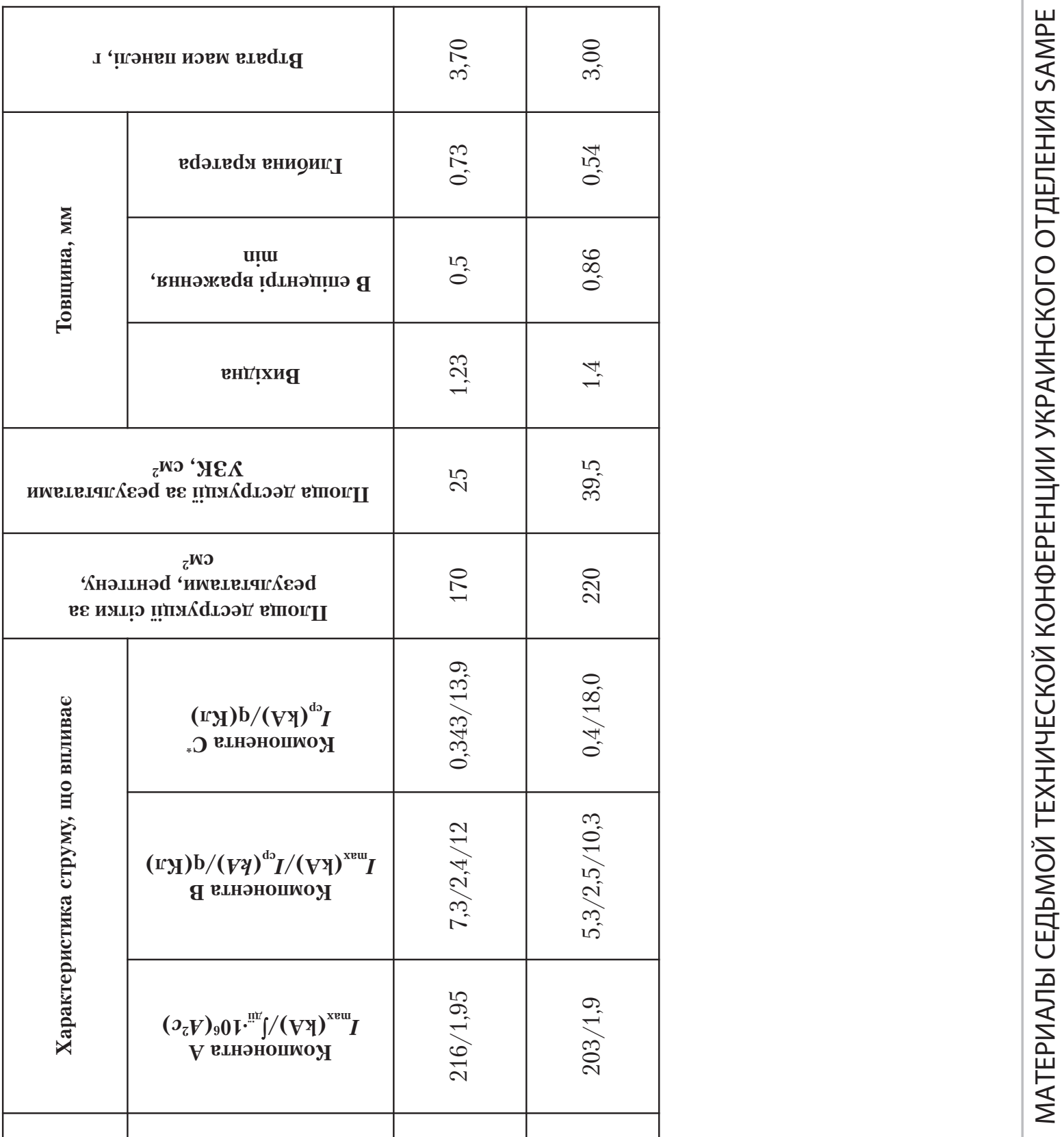

\begin{tabular}{|c|c|c|c|}
\hline \multirow{2}{*}{ 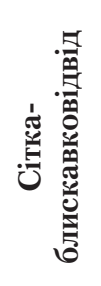 } & оошидш вмdеуW & $\begin{array}{l}\bar{b} \\
\text { Uं } \\
0\end{array}$ & $\underset{\sim}{\stackrel{4}{4}}$ \\
\hline & WW ‘'KLOdI dıəWe!!] & $\stackrel{?}{0}$ & $\tilde{0}$ \\
\hline & 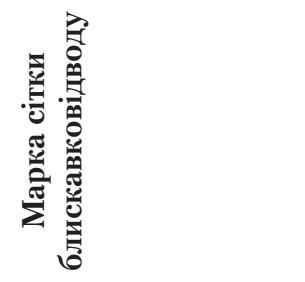 & 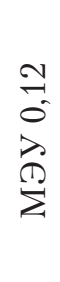 & $\sum_{0}^{\vec{D}}$ \\
\hline & 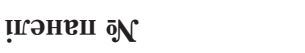 & - & $\sim$ \\
\hline
\end{tabular}




\section{CИCTEMbITC 4/2017}

Нами були вивчені умови заміни в сітках-блискавковідводах свинецьмісткого припою ПОС-61 на безсвинцевий припій на основі олова. Відомо, що в технології паяння дротових з'єднань важливе значення має процес змочування поверхні дроту припійним розплавом [4]. Змочування повинно забезпечити якісну металізацію мідного дроту і надійне з'єднання в місцях контактів петель. Припійний розплав також не повинен суттєво збільшувати величину електричного опору струмовідвідної сітчастої конструкції. При проведенні досліджень по заміні припою ПОС-61 були розглянуті наступні групи безсвинцевих низькотемпературних припоїв [4].

Система $\mathrm{Sn}-\mathrm{Cu}$. Недоліком цих мідьмістких евтектичних сплавів є підвищена температура плавлення (вище температури експлуатації свинецьмістких припоїв) і гірші механічні властивості в порівнянні з іншими безсвинцевими припоями (на основі олова).

Система Sn-Ag. Срібномісткі припої мають хороші механічні властивості і краще паяються, ніж мідьмісткі припої. Ці припої є евтектичними з температурою плавлення $-221^{\circ} \mathrm{C}$. Порівняльні тести паяння таким типом припою і звичайним припоєм, що містить свинець, показують значну перевагу безсвинцевого припою по надійності здійснення процесу паяння.

Система $\mathrm{Sn}-\mathrm{Ag}-\mathrm{Cu}$. Сплав олова, срібла і міді евтектичного складу використовувався задовго до появи припою $\mathrm{Sn}-\mathrm{Ag}$. Перевага такого припою полягає в більш низькій температурі плавлення $\left(217{ }^{\circ} \mathrm{C}\right)$. Стандартні припої марки SAC складу Sn-3,8\%Ag-0,7\%Сu мають кращу надійність і технологічність, ніж безсвинцеві припої, які містять тільки срібло або мідь. Додавання в сплав 0,5 \% сурми дозволило зробити цей тип припою (промислова назва CASTIN) ще більш технологічним і широко використовувати його в промисловості.

Система $\mathrm{Sn}-\mathrm{Ag}-\mathrm{Bi}(\mathrm{Cu}, \mathrm{Ge})$. Температура плавлення такого сплаву становить $200-210^{\circ} \mathrm{C}$, він краще оброблюється пайкою порівняно з іншими безсвинцевими припоями. Додавання $\mathrm{Cu}$ та/або Ge покращує змочування поверхонь, що підлягають пайці, а також покращує міцність паяного з'єднання.

В даній роботі вивчали процес змочування методом лежачої краплі з застосуванням способу капілярного очищення розплаву краплі в процесі експерименту 5 в вакуумі $2 \times 10^{-3}$ Па в температурному інтервалі $250-350^{\circ} \mathrm{C}$. Просочення розплаву через графітовий капіляр (рис. 1) з отвором діаметром до $\sim 10^{-3}$ м дозволяло проводити роздільний нагрів краплі і підкладки, здійснювати капілярне і термовакуумне очищення розплаву. Застосування методу лежачої краплі з використанням способу капілярного очищення дозволяе отримати температурні і кінетичні залежності крайового кута змочування 3 високою відтворюваністю результатів.
Дослідження змочування компактних підкладок із міді марки М1 проводили безсвинцевими розплавами. В якості рідкої фази використовували розплави $\mathrm{Sn}-8 \%$, Bi, припій $\mathrm{SAC}(\mathrm{Sn}-3,8 \% \mathrm{Ag}-0,7 \% \mathrm{Cu})$, O-2 (99,95 \%Sn), CASTIN (Sn-2,5\%Ag-0,7 \%Cu$0,5 \% \mathrm{Sb})$ і для порівняння стандартний припій ПОС-61 ( $\mathrm{Sn}-39 \% \mathrm{~Pb})$. Припої готували попереднім плавленням в графітових тиглях в вакуумі при температурі $350^{\circ} \mathrm{C}$ з металів з вмістом основного компонента до 99,999\% (мас).

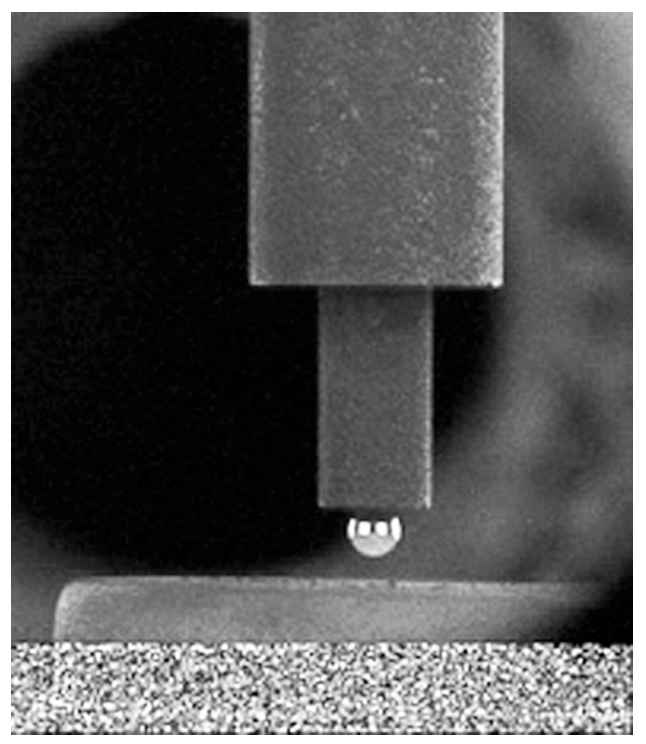

Рис. 1. Графітова крапельниця для очищення металевого розплаву під час експерименту

Результати по змочуванню міді в інтервалі температур $250-350^{\circ} \mathrm{C}$ представлені на рис. 2.

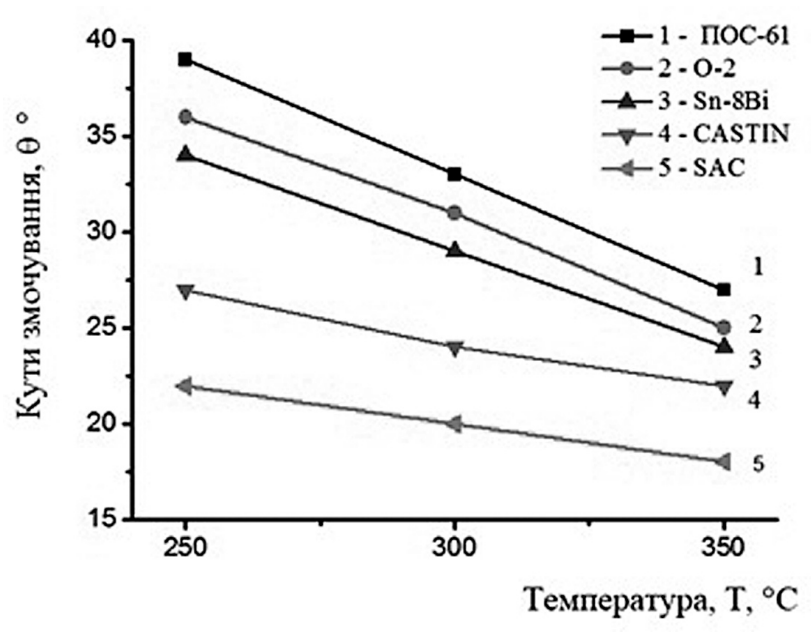

Рис. 2. Температурна залежність змочуваності міді: припоями: 1 - ПОС-61

$2-\mathrm{O}-2(99,95 \% \mathrm{Sn})$

$3-\mathrm{Sn}-8 \% \mathrm{Bi}$

4- CASTIN (Sn-2,5\% Ag-0,7\% Cu-0,5\% Sb)

5 - SAC (Sn -3,8\% Ag - 0,7\% Cu) 
При влученні блискавки у в’язано-паяне сітчасте полотно, в якому разом з дротом, який покритий припоєм також присутні паяні вузли чарунок сітки, важливе значення має як електричний опір дротяних елементів конструкції, так і електричний опір паяних вузлів. Для характеризації струмовідводної здатності блискавкозахисної сітки важливо знати величини електричного опору припоїв i вплив паяння на зміну опору сітки. Тому в роботі вимірювали питомий електричний опір досліджуваних припойних сплавів і в’язано-паяних сіток.

Визначення електричного опору припоїв проводили 4-х точковим методом при кімнатній температурі. Для цього були виготовлені спеціальні пруткові зразки шляхом плавленням припоїв 3 подальшим витягуванням злитків до необхідного діаметру і довжини.

У таблиці 3 представлені результати по визначенню питомого опору припійних сплавів при кімнатній температурі. Отримані результати відрізняються високою повторюваністю.

Було встановлено, що питомий електроопір припоїв значно вище, ніж у міді.
3 мідного нелудженого мікродроту діаметром 0,1 мм з нанесенням безсвинцевого припою марки SAC на мікродріт в процесі паяння сітки. Вказаний діаметр мікродроту був взятий із міркувань доступності, технологічності і досягнення високої електропровідності. Експериментальні вуглецьпластикові панелі з в'язано-паяною сіткою-блискавковідводом СВМ-БП були виготовлені на підприємстві ДП «Антонов» по традиційній технології вакуум-автоклавного формування.

Розрядні випробування дією імітованої блискавки також виконувались за умовами зони 1А. Результати випробувань наведені в таблиці 2 (панель № 2).

Аналіз результатів випробувань показав, що панелі з блискавкозахисною сіткою СВМ-БП, незважаючи на те, що ця сітка,яка виготовлена 3 дроту меншого діаметру, ніж сітка МЭУ 0,12, і відповідно з більшим електроопором дроту, має переваги у значно меншій глибині кратера руйнування панелі та меншій втраті маси. Це пояснюється, в першу чергу, тим, що питомий поверхневий електроопір сітки-блискавковідводу СВМ-БП, особливо в середньокруговому напрямку (табл.1) суттєво

Таблиця 3

Питомий електричний опір припоїв

\begin{tabular}{|c|c|c|}
\hline Припій & Склад припою, мас. \% & р, мкОм·м \\
\hline ПОС-61 & $\mathrm{Sn}-39 \mathrm{~Pb}$ & 0,130 \\
\hline $\mathrm{O}-2$ & $99,95 \mathrm{Sn}$ & 0,105 \\
\hline $\mathrm{SAC}$ & $\mathrm{Sn}-3,8 \mathrm{Ag}-0,7 \mathrm{Cu}$ & 0,099 \\
\hline $\mathrm{Sn}-\mathrm{Bi}$ & $\mathrm{Sn}-8 \mathrm{Bi}$ & 0,140 \\
\hline $\mathrm{Cu}^{*}[6]$ & & 0,0172 \\
\hline $\mathrm{Sn}^{*}[6]$ & & 0,12 \\
\hline
\end{tabular}

Примітка: * Для порівняння

Дослідження змочування компактної міді безсвинцевими припоями порівняно 3 припоєм ПОС-61 показали можливість застосування припою $\mathrm{SAC}(\mathrm{Sn}-3,8 \% \mathrm{Ag}-0,7 \% \mathrm{Cu})$ завдяки найменшому куту змочування, високій рідкоплинності та найнижчому серед досліджених припоїв значенню питомого електроопору.

В наших експериментах для виготовлення зразків вуглецьпластикових панелей була застосована в'язана сітка СВМ-БП (сітка в'язана мідна з безсвинцевим припоєм) (табл. 1), що була виготовлена не відрізняється від поверхневого електроопору сітки МЭУ-0,12. Це теж призводить до зменшення поверхневого електроопору панелі і дисипації значної частини енергії блискавки по їі поверхні.

Щоб пояснити такі якості сітки СВМ-БП, треба взяти до уваги не тільки зменшений питомий електроопір срібномісткого припою SAC порівняно 3 припоєм ПОС-61 (табл. 3), але й особливостями електропровідної структури в’язано-паяної сітки (рис. 3), які створюють механізм одержання її підвищеної електропровідності. 


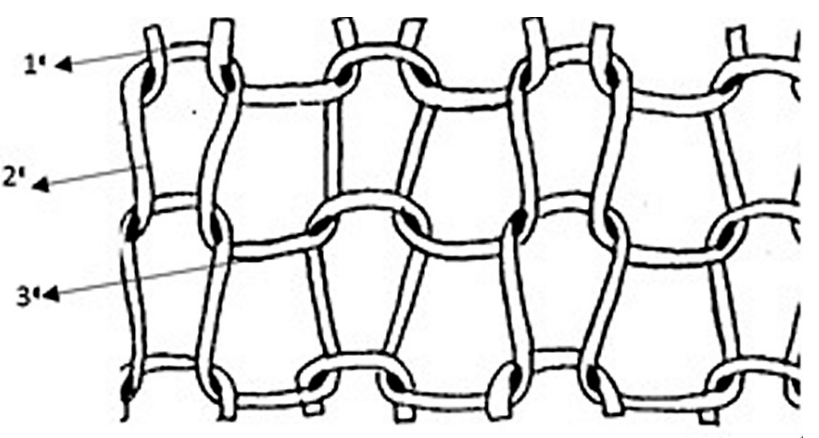

Рис. 3. Схема електропровідної структури в'язано-паяної трикотажної сітки Елементи петлі:

1 - петельна дуга (п.д.);

2 - петельна палиця (п.п.);

3 - протяжка (прот.);

4 - припій.

Електричні опори цих елементів петлі в подальших розрахунках будуть позначатися таким чином:

$R_{\text {п.д. }}-$ опір петельної дуги;

$R_{\text {п.п. }}-$ опір петельної палиці;

$R_{\text {прот. }}$ - опір петельної протяжки;

$R_{\text {прип. }}$ - опір припою.

В трикотажних полотнах петлі, які знаходяться поперек і одержані за один прохід в'язальної каретки, складають петельний ряд. Петлі, які послідовно нанизані одна на одну вздовж полотна , складають петельний стовпчик.

Всі розглянуті сітки - МЭУ-0,08; МЭУ-0,12; СВМ-БП - були вироблені двохлицьовим переплетенням «ластик 1+1», що має як лицьові, так і зворотні петлі. Електропровідну структуру вздовж трикотажного полотна складають лицьові та зворотні петельні стовпчики. Як бачимо на схемі (рис. 3) структура полотна забезпечує електричне з'єднання, в якому електроопір петельного стовпчика складається з суми електроопорів петельних паличок кожного петельного ряду та електроопору припою, що з`єднує їхпо довжині стовпчика суміжними петельними палицями. Тому електроопір

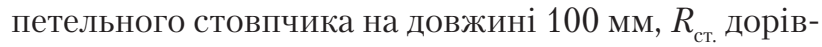
нює електроопору петлі, помноженому на кількість петель на цій довжині (П $)$ :

$$
R_{\text {ст. }}=\frac{R_{\text {пп. }}+R_{\text {прип. }}}{2} .
$$

Відповідно величина електроопору вздовж сітчастого полотна шириною 100 мм буде дорівнювати оберненій кількості петельних стовпчиків (лицьових та зворотних) на цій ширині $\left(\Pi_{\mathrm{r}}\right)$ :

$$
R_{\text {полотна }}^{\prime \prime}=\frac{R_{\text {п.г. }}+R_{\text {прип. }}}{2 \Pi_{\mathrm{r}}} \cdot \Pi_{\mathrm{B}} .
$$

Вираз (2) являє собою величину електроопору квадрата сітчастого полотна розміром 100×100 мм, що виміряне по довжині сітчастого полотна і дорів- нює питомому поверхневому електроопору вздовж полотна $\rho_{s}^{\prime \prime}$.

Електроопір петельного ряду на ширині полотна 100 мм складається (рис. 3) з суми електроопорів петельних дуг, протяжок та припою, який знаходиться у вузлах петель:

$$
R_{\text {пет. ряда }}=\left(R_{\text {п.д. }}+R_{\text {прот. }}+2 R_{\text {прип. }}\right) \Pi_{\text {г }}
$$

Аналогічно, електричний опір по ширині полотна довжиною 100 мм, $R_{\text {полотна }}^{\perp}$ буде дорівнювати величині, яка відповідає виразу:

$$
R_{\text {полотна }}^{\perp}=\frac{\left(R_{\text {п.д. }}+R_{\text {прот. }}+2 R_{\text {прип. }}\right) \Pi_{\text {г }}}{\Pi_{\text {в }}} .
$$

Вираз 4 також відповідає електричному опору квадрата полотна розміром 100×100мм. Він визначається по ширині полотна і являє собою питомий поверхневий електроопір сітчастого полотна вздовж петельних рядів $\rho_{\mathrm{s}}^{\perp}$.

Вирази (2) та (4) показують, що величина електроопору припою в вузлах петель може суттєво впливати на питомий поверхневий електроопір вздовж і поперек в'язано-паяного сітчастого полотна і, відповідно, відбивається на рівні середньокругового опору [7].

Приймаємо до уваги те, що електроопір припою у вузлі петлі дорівнює:

$$
R_{\text {прип. }}=\rho t / S,
$$

де $\rho$ - питомий електроопір припою; $t$ - товщина прошарку припою у вузлі петлі; $S$ - площа прошарку припою у вузлі петлі. Тоді для зменшення електроопору вузла петлі потрібно вибирати припій не тільки 3 низьким рівнем його питомого електроопоpy, а і враховувати при цьому показники змочування ним мідної підкладки.

Товщина краплі рідкого припою та його площа в петельному вузлі залежить від кута змочування мідної поверхні (рис. 4) та їі стану, що оцінюється шорсткістю [6].

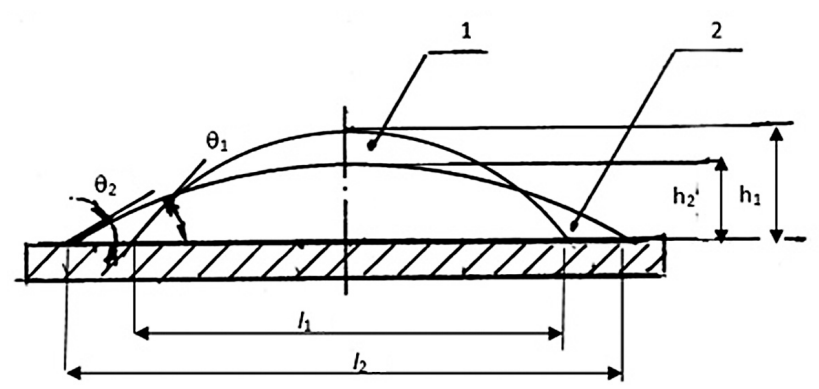

Рис. 4. Схема змочування мідної підкладки краплями припоїв ПОС-61 (1) та SAC (2)

$h_{1}, h_{2}$ - висота крапель припою ПОС-61 та SAC, відповідно

$l_{1}, l_{2}-$ довжина хорди крапель

$\theta_{1}, \theta_{2}-$ крайові кути змочування 


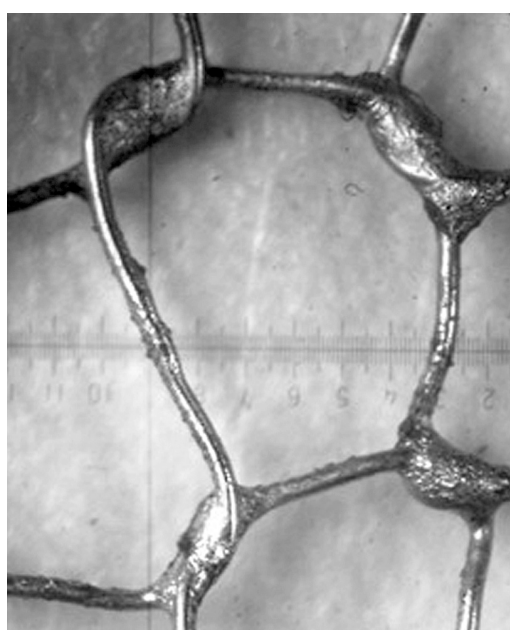

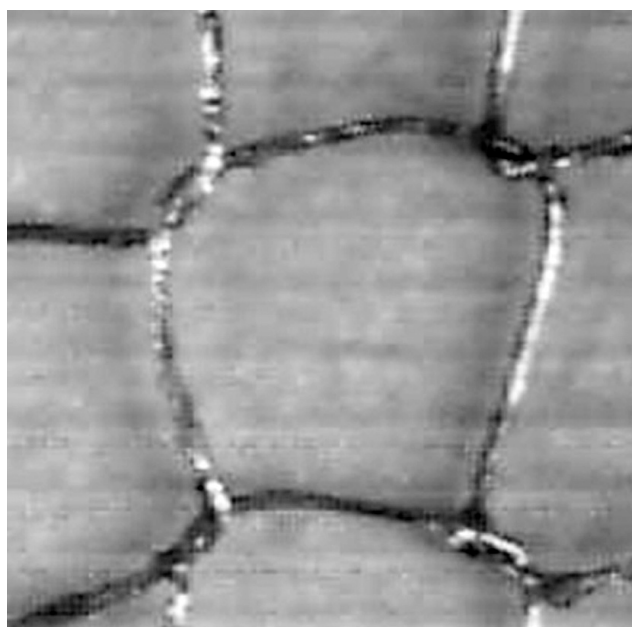

б

Рис. 5. Фрагменти вузлів в'язано-паяних мідних сіток a - сітка МЭУ-0,12 з припоєм ПОС-61; б - сітка СВМ-БП з припоєм SAC

$$
\sin \frac{\theta}{2}=\frac{\ln k^{2}}{\left(\frac{l}{2}\right)^{2} k^{4}=+h^{2}}
$$

де: $k$ - коефіцієнт шорсткості

$$
k=\frac{\gamma_{0 \text { шорст. }},}{\gamma_{0 \text { полір. }}}
$$

де: $\gamma_{0 \text { шорст. }}, \gamma_{\text {ополір. }}-$ висотний показник мікрогеометрії поверхні.

Порівнюючи крайові кути змочування мідної підкладки при температурі 250 С припоїв ПОС-61 та $\mathrm{SAC}$ (рис. 2), маємо відповідно $\theta=37^{\circ}-$ для ПОС-61 та $\theta=23^{\circ}$ - для SAC. Така різниця у кутах змочування позначається на товщині припійних прошарків у петельних вузлах (рис. 5). Це призводить до зменшення електроопору прошарків в сітці СВМ-БП Незважаючи, що електроопір дроту в цій сітці більший, ніж в сітці МЭУ-0,12, питомі поверхневі електроопори обох сіток в середньокруговому напрямку урівняються.

Таким чином заміна припою ПОС-61 в сітчастих струмовідводах на екологічно чистий припій SAC не тільки поліпшує екологічні умови виробництва, але й створює можливість замінити сітку МЭУ0,12 на сітку СВМ-БП. Дуже важливим при цьому $€$ те, що така заміна дозволяє зменшити (на 10-15\%) вагу блискавкозахисного сітчастого покриття, що для використання в авіації є дуже суттєвим.

\section{Висновки}

1. Дисипативні властивості вуглецьпластиків 3 наформованими на поверхню в’язано-паяними сітками збільшуються за рахунок розпаювання при- пою у вузлах при ураженні блискавкою, що гальмує процеси розшарування і руйнування композиту.

2. Аналітично та експериментально показано, що на рівень поверхневого електричного опору в'язано-паяної сітки суттєво впливають кути змочування та питомий електроопір припоїв.

3. Рекомендовано застосовувати безсвинцеві припої на основі олова у в'язано-паяних сіткахблискавковідводах. Визначені кути змочування та температура нанесення покриттів на поверхню мідних дротів.

4. Встановлена можливість заміни в сітках-блискавковідводах свинецьмісткого припою ПОС-61 на екологічно чистий припій $\mathrm{SAC}(\mathrm{Sn}-3,8 \% \mathrm{Ag}-0,7 \% \mathrm{Cu})$. При цьому поліпшуються як екологічні умови, так i електричні властивості сітки-блискавковідводу, а також з'являється можливість зменшення маси сітки за рахунок використання в'язано-паяних сіток, що виготовляють збільш тонкого мідного мікродроту.

\section{Лiтература}

[1] Острик В.Б., Филипенко А.А. Молниезащита углепластиковых элементов конструкции самолёта при тепловом и механическом действиях прямого удара молнии. // Конструкции из композиционных материалов. - 2010. - №1. - С. 34-44.

[2] Пат. № 50188 Україна. МКИ В64 D45/00. Вишняков Л.Р., Коханый В.А., Нешпор А.В., Коханая И.Н. Спосіб пайки петель трикотажної структури з мідного дроту. Заявл. 15.12.09; Опубл. 25.05.10.

[3] Авиационные правила АП-25. // Армак. - 2004.

[4] Красовский В.П., Вишняков Л.Р., Коханый В.А., Красовская Н.А., Ободеева И.Н. Бессвинцовые припои для пайки проволочных сеток на основе медных 
сплавов. // Порошковая металлургия. - 2017. № 1-2. - C. 132-140.

[5] Найдич Ю.В., Красовский В.П. Смачиваемость некоторых неметаллических материалов. // Порошковая металлургия. - 1983. - № 6. - С. 66-68.

[6] Киселев М.Г., Савич В.В., Павич Т.П. Определение краевого угла смачивания на плоских поверхностях // Вестник БНТУ. - 2006. - № 1. - С. 38-41.
[7] Вишняков Л.Р., Красовский В.П., Чернявский И.И. Расчет и измерение электросопротивления анизотропных сетчатых молниеотводов для листовых конструкций из углепластиков // Технологические системы. - 2016. - № 4. - С. 17-19.

Vishnyakov L. R. ${ }^{1}$, Krasovskyy V. P. ${ }^{1}$, Kokhana I. N. ${ }^{1}$, Chernyavsky I. I. ${ }^{2}$, Kokhanyi V. A. ${ }^{1}$, Yaremenko O. P. ${ }^{1}$, Krasozskya N.A. ${ }^{1}$

${ }^{1}$ Frantsevich Institute for Problems of Materials Science of National Academy of Science of Ukraine.

Ukraine, Kiev

${ }^{2}$ ANTONOV, State-owned Enterprise. Ukraine, Kiev

\section{DEVELOPMENT OF KNOT-SOLDERED LIGHTNING-CONDUCTORS WITH LEAD-FREE SOLDER FOR PROTECTION OF POLYMERIC COMPOSITES FROM ACTION OF DIRECT LIGHTNING STROKE}

The mechanism of light-emitting energy dissipation in direct contact with a carbon-fiber structure, which is protected by a grid-lightning rod, is considered. The geometric model of the flow-water structure of the knot-soldered mesh structure is proposed, electrical structural chains, which determine the electrical conductivity of the web, are considered, the method of calculation of a specific surface electrical resistance is developed. A methodical approach for studying the corners of wetting of copper with lead-free soldering has been developed, their specific electric supports have been studied. It is recommended to use a lead-free alloy of type SAC (Sn-3,8\% Ag-0,7\% Cu) as a siphon of a mesh lightning rod. [dx.doi.org/10.29010/081.5]

Keywords: lightning protection; carbon fiber mesh canvas; metal wire; connecting dissipation of energy; relaxation.

\section{References}

[1] Ostrik V.B., Filipenko A.A. Lightning protection of carbon-fiber structural elements of aircraft during thermal and mechanical actions of direct lightning strike. // Constructions from composite materials. - 2010. - No. 1. - P. 34-44.

[2] Pat. № 50188 Ukraine. MKI B64 D45 / 00. Vishnyakov L.R., Kokhanyi V.A., Neshpor A.V., Kokana I.N. Method of soldering of knitting structure hinges from copper wire. Declared 15.12.09; Pubwished 25.05.10.

[3] Aviation Rules AP-25.// Armac. - 2004.

[4] Krasovskii V. P., Vishnyakov L.R., Kokhanyi V.A., Krasovskaya N.A., Obodeeva I.N. Lead-free solders for soldering wire mesh based on copper alloys. // Powder metallurgy . - 2017. - No. 1-2 . - P. 132-140.

[5] Naidich Yu.V., V.P. Krasovskiy Wetability of some nonmetallic materials. // Powder metallurgy. - 1983. - No. 6. P. 66-68

[6] Kisilev M.G., Savich V.V., Pavich T.P. Determination of the contact angle of wetting on flat surfaces // Bulletin of BNTU. - 2006. - №1.- P. 38-41.

[7] Vishnyakov L.R., Krasovsky V.P., Chernyavsky II Calculation and measurement of the electrical resistivity of anisotropic network lightning arresters for sheet structures made of carbon plastic materials // Technological Systems . - 2016. No. 4. - P. 17-19. 